\title{
Some Aspects of the Synoptic Mesoclimatology of the Armidale District, New South Wales, Australia
}

\author{
RUSSELL D. THOMPSON \\ Depl. of Geography, University of Guelph, Ontario, Canada
}

(Manuscript received 12 April 1972, in revised form 9 March 1973)

\begin{abstract}
The mesoscale temperature and precipitation variations in the Armidale district are classified according to the synoptic pressure pattern and airflow direction. These variations are found to correspond to the relief characteristics of the Northern Tablelands region.

The precipitation distribution is directly related to the elevation changes, particularly with easterly maritime anticyclonic circulations. Temperature variations are influenced by 1) surface heat accumulation [steepened lapse rates] and cold air drainage, and 2) the insolation concentration on the north facing slopes of the west-east oriented Dumaresq Valley. The most pronounced temperature contrasts are only experienced under conditions of anticyclonic stability, both maritime and continental. No temperature contrasts are found in cyclonic maritime circulations because of the associated clouds and turbulence.
\end{abstract}

\section{Introduction}

Since 1950 climatologists have become increasingly concerned with the relationship between the distribution of climatic parameters and the advective elements of climate associated with synoptic pressure patterns and airflow direction (for example, Lamb, 1950; Baur, 1951; Godske, 1959; Barry, 1967; Mosino, 1964; Bluthgen, 1965.) However, Australian climatologists have largely neglected the synoptic controls of the continent's climate, despite the periodic flooding and drought disasters (e.g., New South Wales in 1963 and 1965-66, respectively), except for Foley (1945) who correlated the development of frosts in New South Wales to the prevailing synoptic patterns.

The objective of this paper is to develop a synoptic classification of airflow types occurring over the Armidale district of New South Wales, Australia (Fig. 1), in an attempt to determine the influence of atmospheric circulations on rainfall and temperature distributions over the area. In order to determine the spatial variations of temperature and precipitation, 18 climatological stations were established in the Armidale district with site locations chosen to reflect variations in elevation, slope, aspect and urbanization (Fig. 1). Each station was equipped with an instrument shelter, hygrometer, maximum/minimum thermometer, hygrothermograph and raingage. Observations were made daily at 0900 local time for the one-year period 1 October 1966 to 30 September 1967. The distribution of temperature and precipitation was correlated with changing synoptic pressure patterns and airflow circulations, using a scheme based on the Lamb (1950) classification which is illustrated in Table 1.
The classification recognized eight major airflow types which corresponded with cardinal compass points and which represented the general geostrophic airflow in the lower troposphere. These major types were related to the prevailing cyclonic/anticyclonic situation and the resultant 18 hybrid categories represented a combination of the general airflow circulation and pressure steerage [e.g., eight "cardinal" cyclonic types ( $\mathrm{CN}$,

TABLE 1. Classification of airflow types over northeast New South Wales.

\begin{tabular}{|c|c|c|}
\hline $\begin{array}{c}\text { Combination } \\
\text { types }\end{array}$ & $\underset{\text { categories* }}{\text { Hybrid }}$ & $\begin{array}{l}\text { Steerage of pressure } \\
\text { systems }\end{array}$ \\
\hline $\begin{array}{l}\text { Airflow } 1\left(A_{1}\right) \\
\text { (Cyclonic } \\
\text { maritime) }\end{array}$ & 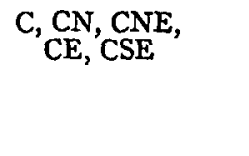 & $\begin{array}{l}\text { Subtropical cyclogenesis to } \\
\text { the north of or over New } \\
\text { South Wales; maritime } \\
\text { airflow off the Tasman } \\
\text { Sea }\end{array}$ \\
\hline $\begin{array}{l}\text { Airflow } 2\left(\mathrm{~A}_{2}\right) \\
\text { (Cyclonic } \\
\text { continental) }\end{array}$ & $\begin{array}{l}\mathrm{CSW}, \mathrm{CW}, \\
\mathrm{CNW}, \mathrm{CS}\end{array}$ & $\begin{array}{l}\text { Frontal cyclogenesis to the } \\
\text { south of New South } \\
\text { Wales in winter; conti- } \\
\text { nental airflow off inland } \\
\text { Australia. }\end{array}$ \\
\hline $\begin{array}{l}\text { Airflow } 3\left(\mathrm{~A}_{3}\right) \\
\text { (Anticyclonic } \\
\text { maritime) }\end{array}$ & $\begin{array}{l}\text { AN, ANE, } \\
\text { AE, ASE }\end{array}$ & $\begin{array}{l}\text { Anticyclogenesis to the } \\
\text { south of New South } \\
\text { Wales in summer with } \\
\text { ridges extending into the } \\
\text { northeast of the state } \\
\text { from the Tasman Sea } \\
\text { and maritime airflows. }\end{array}$ \\
\hline $\begin{array}{c}\text { Airflow } 4\left(\mathrm{~A}_{4}\right) \\
\text { (Anticyclonic } \\
\text { continental) }\end{array}$ & $\begin{array}{l}\text { ASW, AW, ANW, } \\
\text { AS, A }\end{array}$ & $\begin{array}{l}\text { Anticyclogenesis to north } \\
\text { of or over New South } \\
\text { Wales in winter with } \\
\text { continental airfows. }\end{array}$ \\
\hline
\end{tabular}

* See text for definitions. 


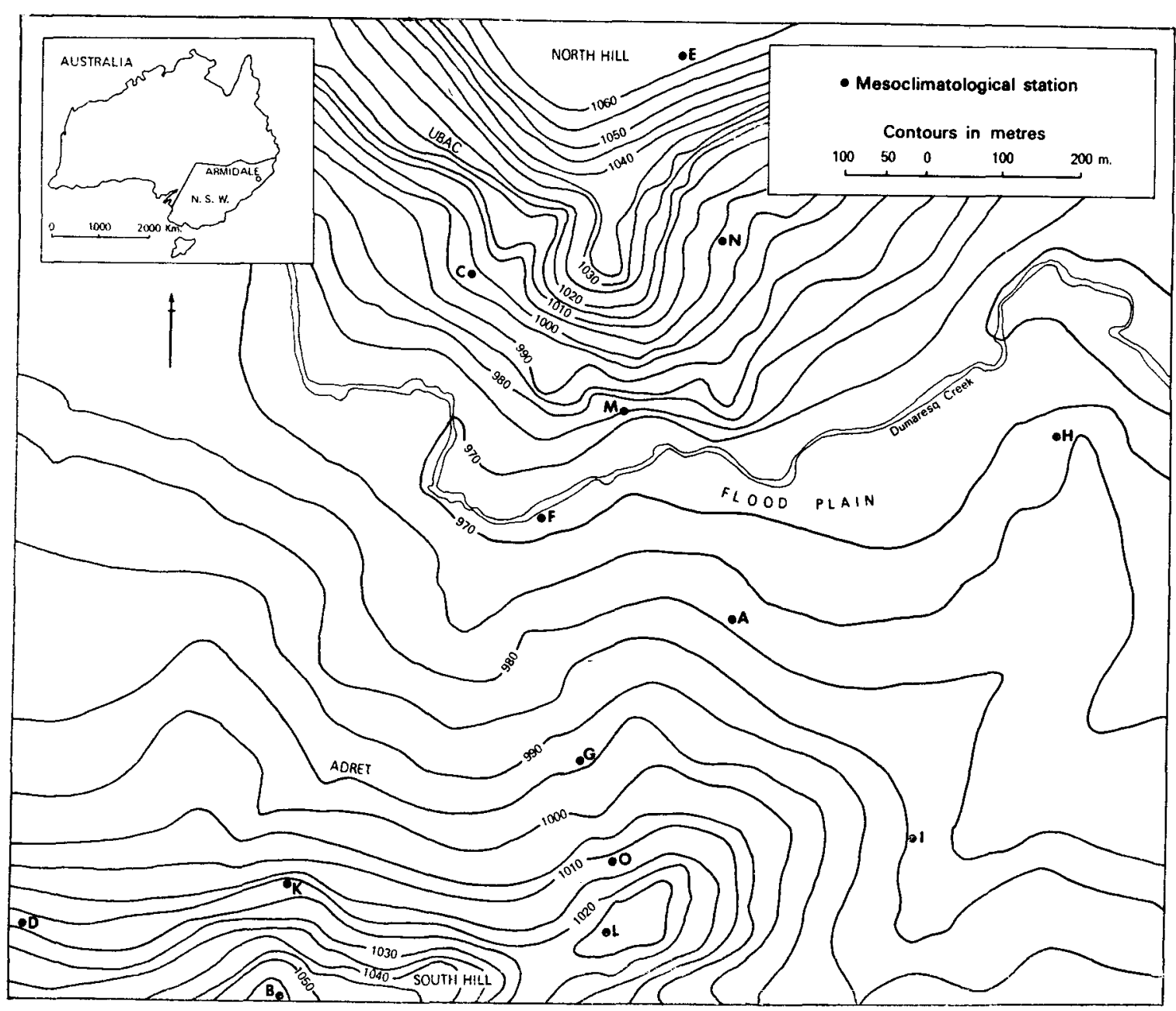

Frg. 1. Surface elevation contours of the Armidale district and location of mesoclimatological stations.

CNE, etc.); eight "cardinal" anticyclonic types (AN, ANE, etc.); C type (cyclonic center over the district); and $A$ type (anticyclonic center over the district)]. However, the airflows were grouped into four main combination types to facilitate statistical analyses of small-sample distributions. The associations between airflow types and precipitation-temperature distribution patterns were determined by chi-square, correlation coefficient, and Kolomorogov-Smirnov tests.

\section{Factors influencing the local climate in the Armidale district}

\section{a. Regional environments and relief forms}

The study area is located at $30^{\circ} 31^{\prime} \mathrm{S}$ and $151^{\circ} 36^{\prime} \mathrm{E}$ and is situated on the eastern periphery of the Australian continent (Fig. 1), some $132 \mathrm{~km}$ from the coast. It is an area of outstanding thermal contrasts reflecting the juxtaposition of warm moist air of the Pacific to the east and the dry air of the continental interior to the west with its obvious seasonal temperature differences.

The structure and physiography of northeast New South Wales are dominated by the complex Eastern Highland Zone (Hills, 1966). The Armidale district occupies the high tablelands section of this escarpment with an altitude around $985 \mathrm{~m}$. However, this surface is characterized by distinctive local relief contrasts since the Dumaresq Creek has carved out a narrow, west-east trending valley with distinctive interfluvial areas of North and South Hills some $100 \mathrm{~m}$ above the lowest floodplain areas (Fig. 1).

\section{b. Synoptic pressure patterns and airflow circulations}

Cyclogenesis and anticyclogenesis in the New South Wales area result from dynamic and thermal energy transfers and are associated with distinctive airflow circulations. The relationships are evident from the following discussion and the seasonal distribution of each airflow type is indicated in Table 2. 


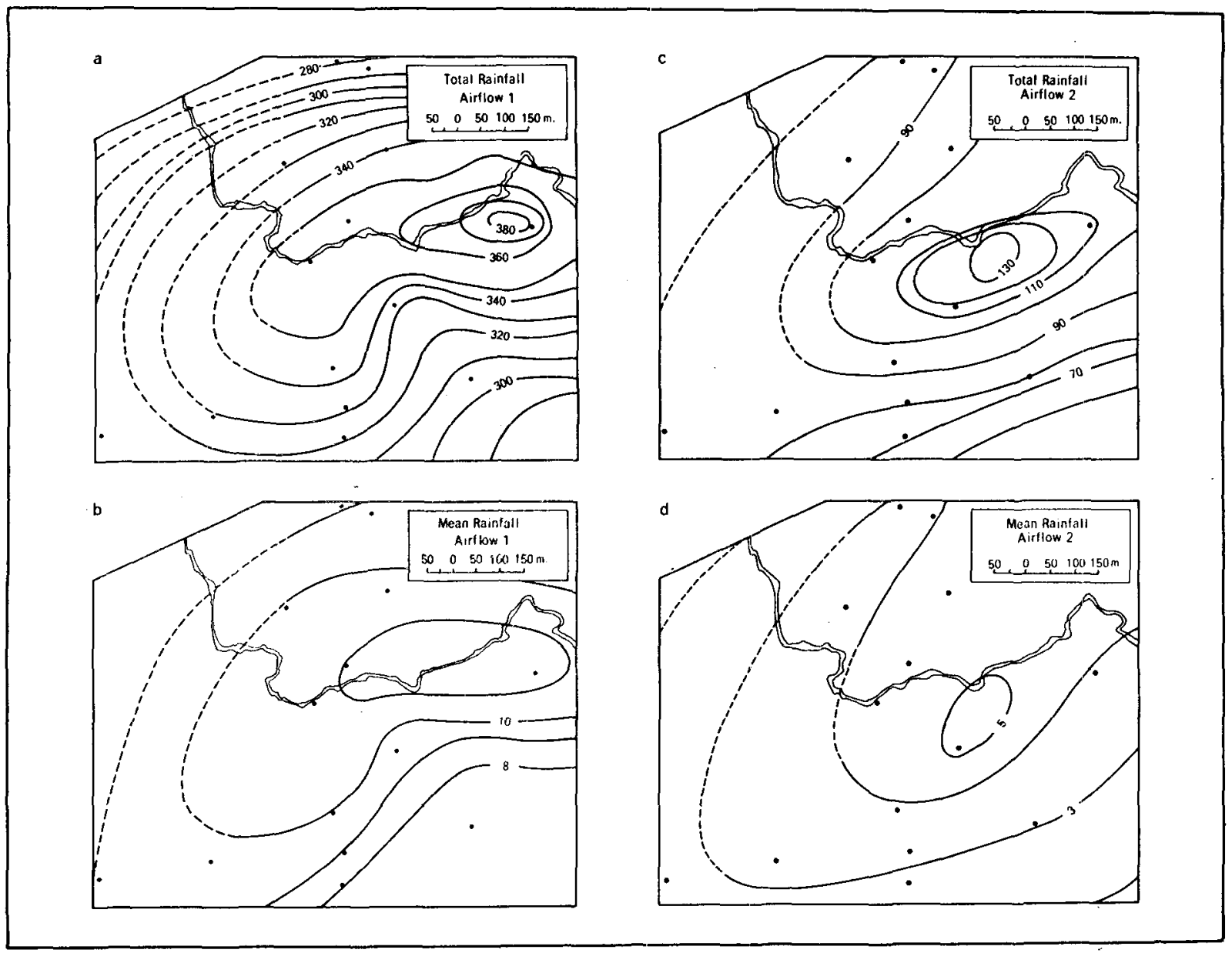

FIG. 2. Airflows 1 and 2 with corresponding total and mean rainfall distributions in the Armidale district.

\section{AIRFLOW 1}

These circulations are related to cyclonic systems which are located to the north of Armidale and are influenced by the transfer of moist warm air from the Pacific Ocean. Cyclogenesis occurs throughout the year but tends to dominate the summer (30\% frequency) and winter seasons (31\% frequency). Summer cyclogenesis is mainly associated with the intertropical convergence zone which migrates into the north of Australia and adjacent oceans during the hot summer

TABLE 2. Seasonal distribution of surface airflow frequencies in the Armidale district, New South Wales (1 October 196630 September 1967).

\begin{tabular}{|c|c|c|c|c|c|c|c|c|c|c|}
\hline \multirow{2}{*}{$\frac{\begin{array}{c}\text { Airflow } \\
\text { type }\end{array}}{1}$} & \multicolumn{2}{|c|}{$\begin{array}{c}\text { Summer } \\
\text { (Dec-Feb) } \\
\text { (no.) }(\%)\end{array}$} & \multicolumn{2}{|c|}{$\underset{\text { (Mar-May) }}{\text { Autumn }}$} & \multicolumn{2}{|c|}{$\begin{array}{l}\text { Winter } \\
\text { (Jun-Aug) }\end{array}$} & \multicolumn{2}{|c|}{$\begin{array}{l}\text { Spring } \\
\text { (Sen-Nov) } \\
\text { (no.) (\%) }\end{array}$} & \multicolumn{2}{|c|}{ (no.) ${ }^{\text {Year }}(\%)$} \\
\hline & 16 & 30 & 9 & 17 & 17 & 31 & 12 & 22 & 54 & 100 \\
\hline 2 & 4 & 9 & 5 & 11 & 16 & 35 & 21 & 4.5 & 46 & 100 \\
\hline 3 & 64 & 35 & 59 & 33 & 26 & 14 & 33 & 18 & 182 & 100 \\
\hline 4 & 6 & 7 & 19 & 23 & 33 & 40 & 25 & 30 & 83 & 100 \\
\hline Total & 90 & & 92 & & 92 & & 91 & & 365 & \\
\hline
\end{tabular}

months. Thermal lows and related troughs migrate across northern New South Wales, with the resultant convergence and moist easterly airflow occasionally accentuated by the formation of deep depressions in the "dip" southward of active troughs. Tropical cyclones are complex and violent thermal lows which develop over the Coral Sea, between December and April especially, and have a normal trajectory along the coast with a vigorous CSE/CE airflow over Armidale on the western periphery of the disturbance.

Winter cyclogenesis and its maritime circulation are associated with the formation of deep complex depressions off the south Queensland coast to the northeast of the study area. This region represents a zone of strong baroclinicity related to pronounced temperature contrasts between the land mass and adjacent ocean, especially when warm ocean currents exist offshore (Bureau of Meteorology, 1963).

\section{AIRFLOW 2}

These circulations are related to cyclonic systems which are located to the south of Armidale and which 

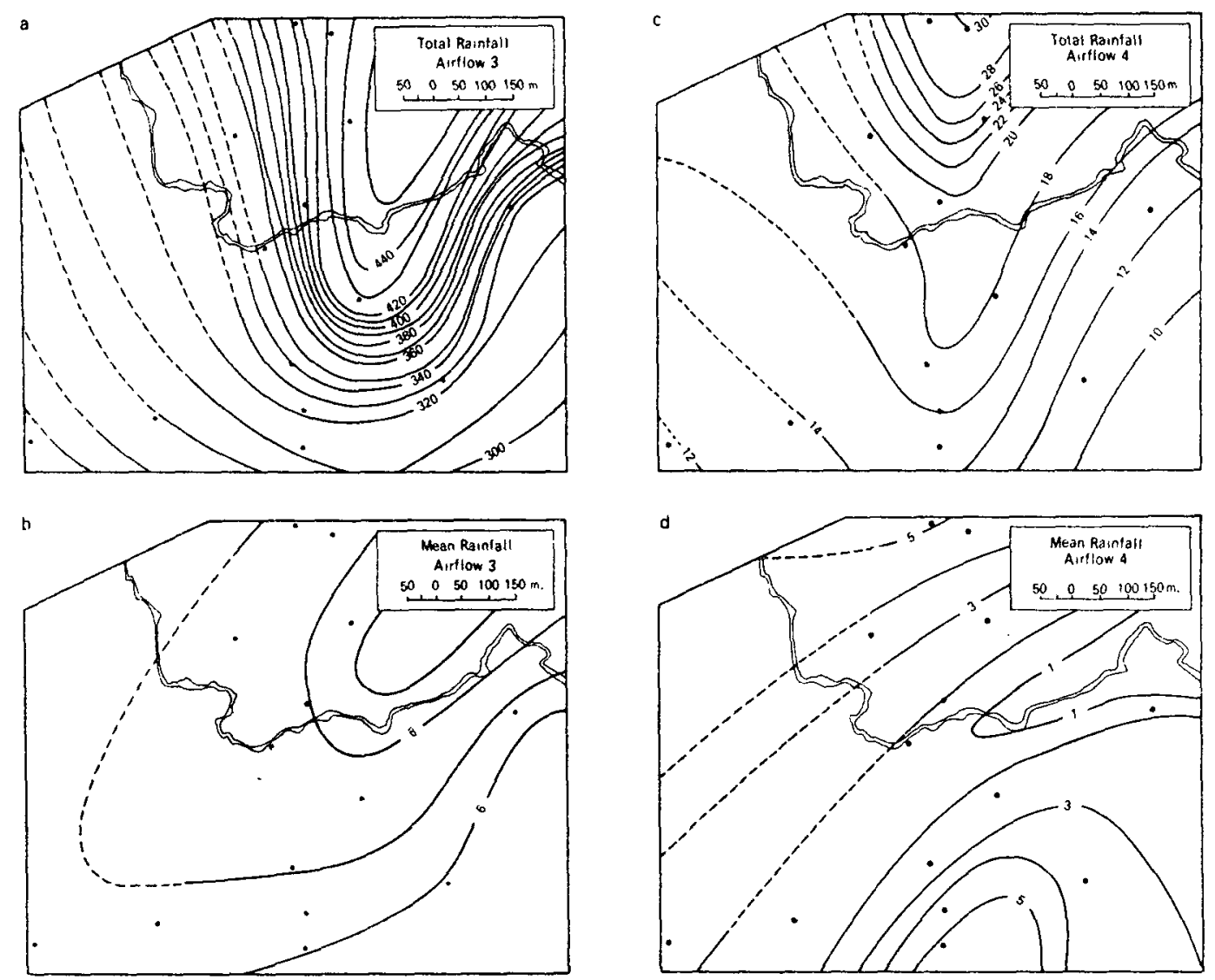

Fig. 3. As in Fig. 2 except for airfows 3 and 4.

stimulate a continental airflow from the interior of Australia, with the advected cold air in winter occasionally accentuated by the subpolar source of southerly (CS) airflows (i.e., the "southerly burster" of the region, immediately behind the cold front). The cyclogenesis dominates the winter/spring seasons ( $80 \%$ frequency) and is associated with the formation of wave depressions to the south of the continent, between latitudes $40^{\circ}-50^{\circ}$ south, along active polar fronts where the baroclinicity extends to the 500-mb level (Hannay, 1960). Troughs and related cold fronts migrate across Armidale, mostly between adjacent quasi-stationary anticyclones, especially in winter/spring when the southern baroclinicity is strongest and when the blocking anticyclones have migrated north of latitude $30^{\circ}$.

\section{ATrFlows 3 AND 4}

These circulations are influenced by the dynamic anticyclogenesis which dominates Australia related to the upper tropospheric convergence on the equatorward side of the subtropical jet stream (Barrett, 1967). The seasonal migration of the subtropical jet between 20 and
$55 \mathrm{~S}$ influences the actual trajectory of the anticyclone, which controls the airflow circulation over northern New South Wales. For example, the northern periphery of the cell is responsible for counterclockwise maritime (Airflow 3) circulations whereas the southern edge is associated with westerly continental (Airflow 4) types.

Airflow 3 circulations dominate the summer and fall (68\% frequency) when the anticyclones track well to the south of the continent (associated with the poleward shift of the weak jet stream) and extend ridges northward over the Armidale district, stimulating the maritime airflow. It should be noted that the uplift of these airflows over the coastal escarpment alters the prevailing dynamic subsidence and causes considerable cloud cover and precipitation.

Airflow 4 circulations dominate the winter and spring ( $70 \%$ frequency) when the anticyclones track over central Australia related to the equatorward migration of a strong $(>180 \mathrm{kt})$ and persistent jet stream. The Armidale district is now influenced by the southern periphery of the anticyclones which advects cold, dry air from the interior. 
TABLE 3. Rainfall totals and means (mm) associated with airflow circulations in the Armidale district, New South Wales (1 October 1966-30 September 1967).

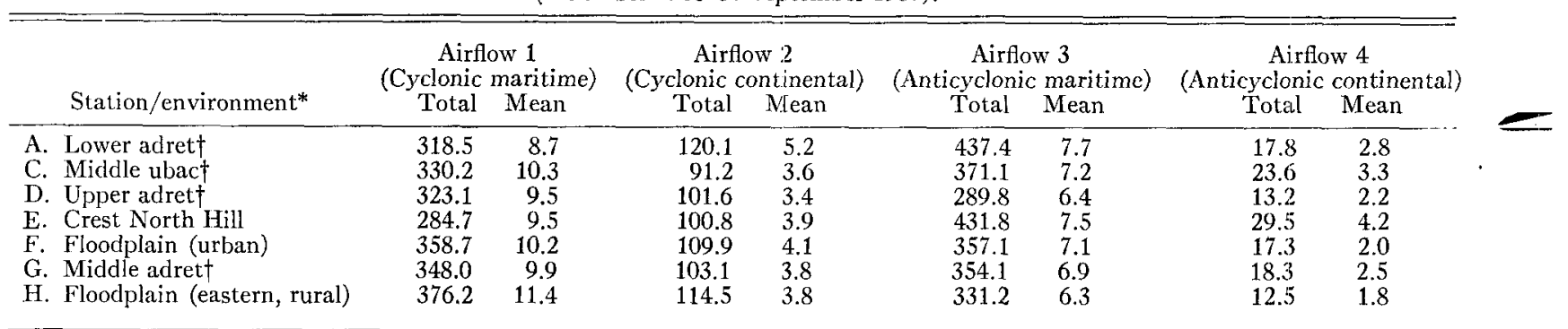

* Station letters refer to locational map (Fig. 1).

$\dagger$ Adret, north-facing warm slopes; ubac, south-facing cool slopes.

\section{Mesoclimatic characteristics and airflow types a. Rainfall}

The distribution is illustrated in Table 3 and Figs. 2 and 3 , where the spatial variations are mostly associated with elevation differences in the district. However, other independent variables such as raingage exposure complicate the spatial patterns. The total rainfall of the cyclonic airflows 1 (maritime) and 2 (continental) was concentrated over the eastern floodplain and was particularly heavy with the moist air of the former circulation where the rainfall exceeded $370 \mathrm{~mm}$ (Figs. 2a and 2c). The dynamic convergence of airflow 1 and the frontal uplift of airflow 2 appeared to be quite independent of relief contrasts in the area since the hillcrest rainfall was considerably below that of the floodplain, especially in the eastern parts where surface heat accumulation was responsible for steepened lapse rates well above the dry adiabatic rate (Section 3b). Mean rainfall relationships (Figs. $2 \mathrm{~b}$ and $2 \mathrm{~d}$ ) supported the total distribution patterns in terms of rainfall intensity concentration in the eastern floodplain. The cyclonic maritime (airflow 1) mean exceeded $11 \mathrm{~mm}$, representing the highest intensity value of the four airflow circulations, and was approximately twice as high as the cyclonic continental (airflow 2) value.

The total rainfall of anticyclonic airflow 3 (maritime) and airflow 4 (continental) circulations (Figs. 3a and 3c) was concentrated over North Hill since the orographic uplift altered the basic subsidence and divergence of the prevailing high pressure systems. The rainfall deficiency in the lower southwestern part of the district was most pronounced with the airflow 3 circulation (Fig. 3a) where the total rainfall was less than $290 \mathrm{~mm}$ compared to over $440 \mathrm{~mm}$ on the crest of North Hill. This reflects the easterly source of the advected moisture and the sensitivity of unstable tropical maritime (AN, ANE) airflows with regard to orographic displacement. The mean rainfall pattern of airflow 3 (Fig. 3b) confirmed the total rainfall distribution, reaching a peak over the eastern flanks of North Hill. The airflow 4 mean rainfall (Fig. 3d) varied between 1 and $5 \mathrm{~mm}$, which emphasized the continentality of the circulation. It should be noted that the highest intensity was recorded over the South Hill crest which reflects the southerly source of the advected moisture, since over $80 \%$ of the rainfall in this circulation type was associated with AS or ASW airflows.

The statistical level of the association between mean rainfall totals and airflow circulation over the district was determined by correlation coefficient testing. A low degree of positive correlation was recorded in terms of rainfall variations associated with the cyclonic continental airflow $2(r=+0.10)$ and the anticyclonic continental airflow $4(r=+0.52)$. Furthermore, correlation significance testing indicated that both these values

TARLE 4. Mean maximum temperature $\left({ }^{\circ} \mathrm{C}\right)$ and airflow types for the Armidale district, New South Wales (1 October 1966-30 September 1967).

\begin{tabular}{|c|c|c|c|c|c|c|c|c|c|c|c|c|}
\hline \multirow[b]{2}{*}{ Station/environment } & \multicolumn{3}{|c|}{$\begin{array}{c}\text { Airflow } 1 \\
\text { (Cyclonic maritime) }\end{array}$} & \multicolumn{3}{|c|}{$\begin{array}{c}\text { Airflow } 2 \\
\text { (Cyclonic continental) }\end{array}$} & \multicolumn{3}{|c|}{$\begin{array}{c}\text { Airflow } 3 \\
\text { (Anticyclonic maritime) }\end{array}$} & \multicolumn{3}{|c|}{$\begin{array}{c}\text { Airflow } 4 \\
\text { (Anticyclonic continental) }\end{array}$} \\
\hline & Year & Winte & Summer & Year & Winter & Summer & Year & Winter & Summer & Year & Winter & Summer \\
\hline A. Lower adret & 20.0 & 12.5 & 27.1 & 18.3 & 13.9 & 27.3 & 21.4 & 13.3 & 26.1 & 16.1 & 12.9 & 23.5 \\
\hline C. Middle ubac & 18.9 & 11.5 & 26.3 & 17.3 & 12.9 & 26.7 & 20.6 & 12.6 & 25.4 & 15.8 & 11.9 & 23.3 \\
\hline D. Upper adret & 19.3 & 11.6 & 26.5 & 17.6 & 12.9 & 26.5 & 20.4 & 13.1 & 25.2 & 15.1 & 11.8 & 22.8 \\
\hline E. Crest North Hill & 18.8 & 11.2 & 26.1 & 17.0 & 12.6 & 26.5 & 20.5 & 12.1 & 24.8 & 15.2 & 10.3 & 22.9 \\
\hline F. Floodplain (urban) & 19.9 & 11.6 & 27.1 & 18.3 & 13.2 & 26.9 & 21.4 & 12.9 & 26.6 & 16.2 & 12.5 & 23.7 \\
\hline G. Middle adret & 19.4 & 12.6 & 26.3 & 18.0 & 13.9 & 26.5 & 20.6 & 13.8 & 25.8 & 15.7 & 13.3 & 23.3 \\
\hline H. Floodplain (eastern) & 19.8 & 12.2 & 27.4 & 18.4 & 13.8 & 27.8 & 21.8 & 13.2 & 26.7 & 16.5 & 12.3 & 24.3 \\
\hline
\end{tabular}

N.B. 1. The temperature difference between stations $\mathrm{E}$ and $\mathrm{H}$ indicates the degree of surface heat accumulation when the $\mathrm{E} / \mathrm{H}$ lapse rate exceeded the dry adiabatic rate $\left[1.0 \mathrm{C}(100 \mathrm{~m})^{-1}\right]$.

N.B. 2. The temperature difference between stations $\mathrm{C}$ and $\mathrm{G}$ (at the same elevation) indicates the degree of adret heating. 

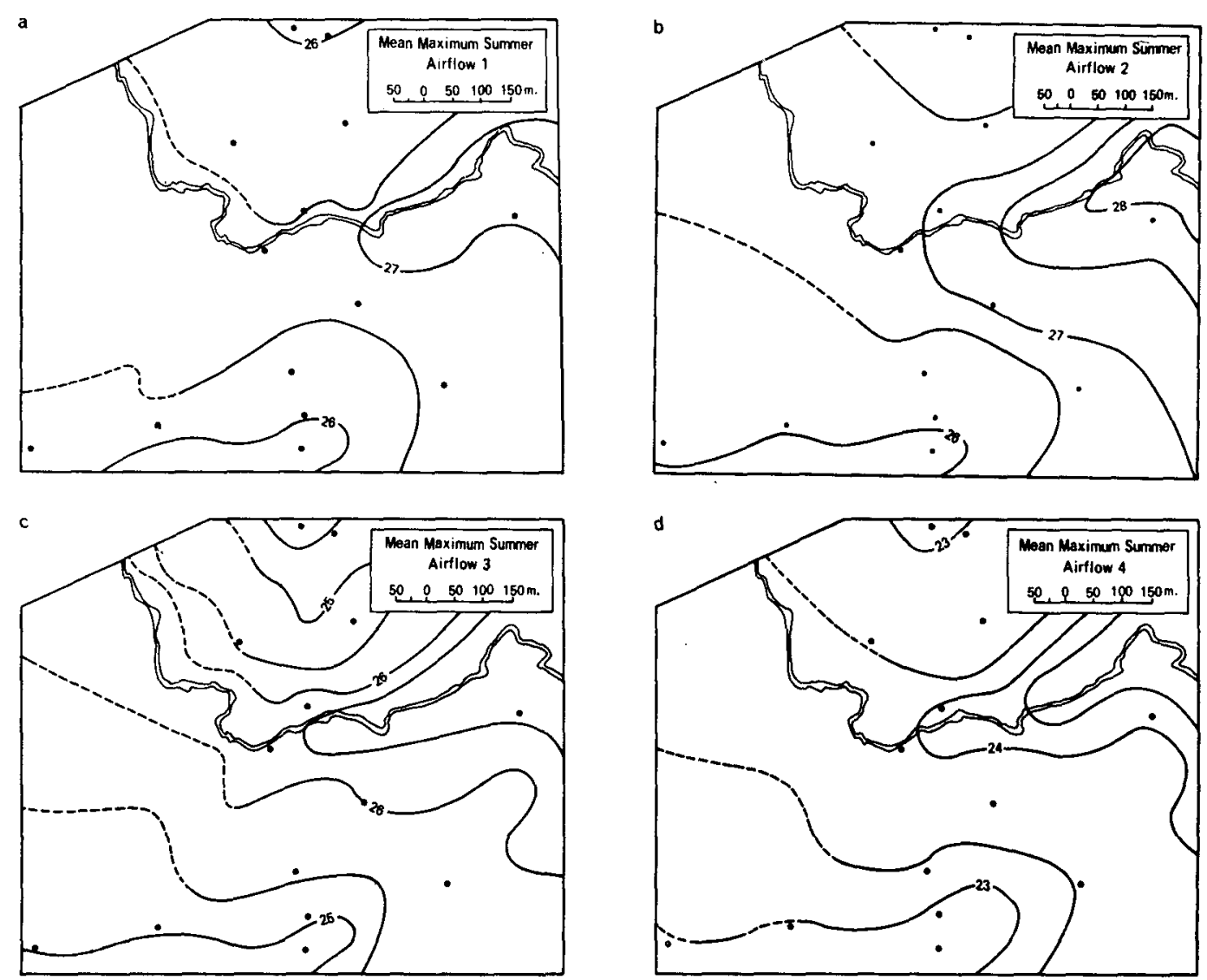

FIG. 4. Airflows 1-4 and the mean maximum summer temperature distribution, illustrating surface heat accumulation in the foodplain.

were not statistically significant at the arbitrary $5 \%$ level. Conversely, a high degree of positive correlation characterized the cyclonic maritime airflow 1 $(r=+0.94)$ and anticyclonic maritime airflow 1 $(r=+0.74)$, and both these values were significant below the 5\% level, which supports the spatial associations described above.

\section{b. Temperature}

\section{1) Maximum temperatures}

The distribution is influenced by the relief of the area since the sheltered eastern floodplain experiences significant surface heat accumulation (lapse rate steepening) on clear stable anticyclonic days, when stagnant air is appreciably heated by the thermal (longwave) radiative process. Under these conditions, the maximum temperature difference between the floodplain and the hillcrest exceeds that attributable to the dry adiabatic rate $\left[1.0 \mathrm{C}(100 \mathrm{~m})^{-1}\right]$.

The maximum temperature pattern was also modified by the role of aspect, which affected the north/south facing slopes of the west-east oriented Dumaresq Valley. The north (sun) facing slopes receive a much greater insolation concentration and duration, particularly in the winter season, and these "warm" slopes are termed adret. Conversely, the south facing slopes experience an insolation and heat deficiency since the angle of solar incidence is reduced quite considerably and because these "cool" slopes (termed ubac) are in the shade for a greater part of the day.

The relationships between mean maximum temperatures and airflow types in the district are indicated in Table 4 and Figs. 4 and 5. The annual maximum and summer maximum temperature distributions were influenced by surface heat accumulation in the eastern floodplain. The former distribution recorded steepened lapse rates with most airflow types, where the dry adiabatic rate was exceeded by between 0.3 and $0.4 \mathrm{C}$. The only exception was airflow 1 where the recorded lapse rate was identical to the dry adiabat, and was related to the turbulence/cloud cover of the cyclonic maritime circulation.

Fig. 4 illustrates the distribution of summer maximum 

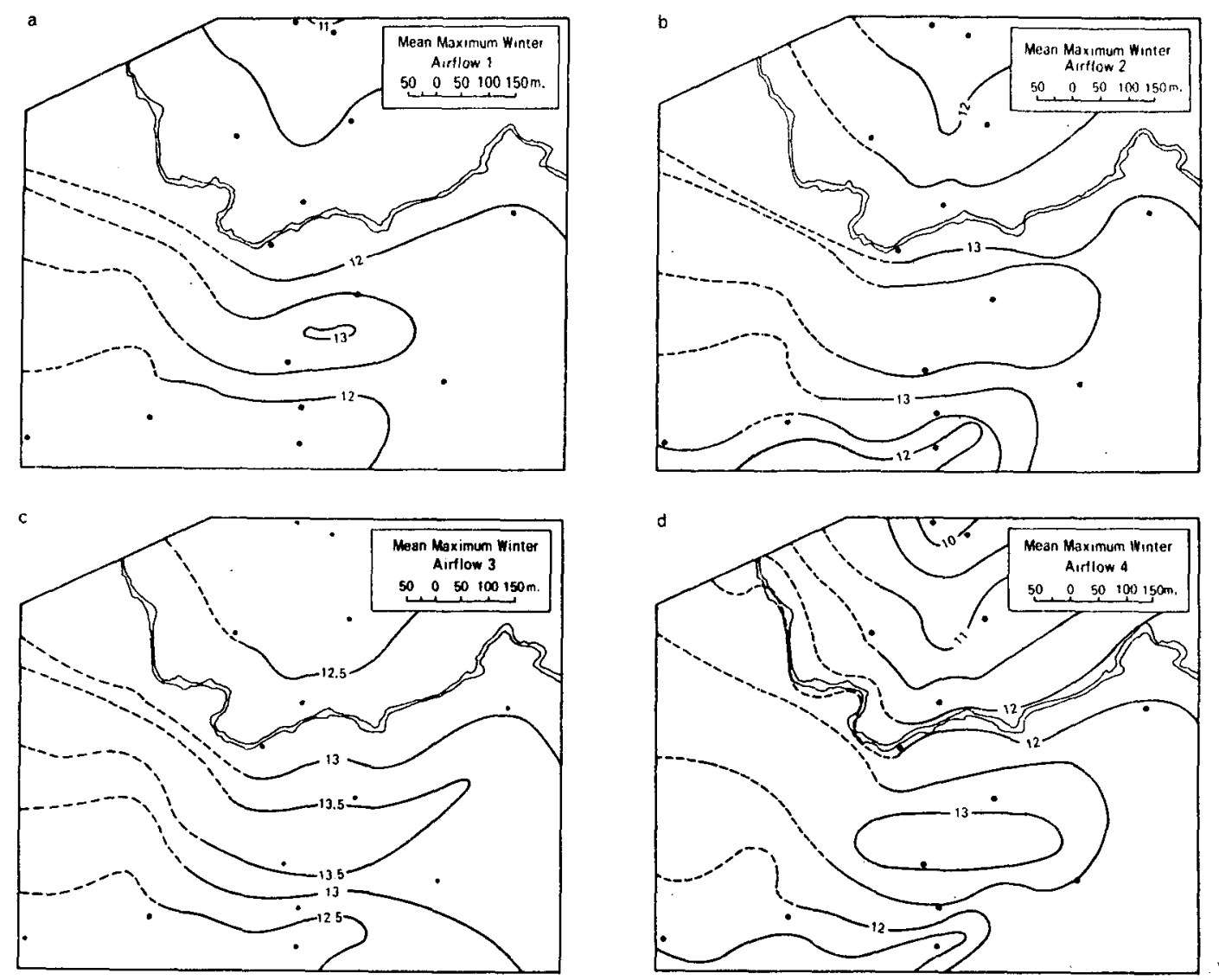

FIG. 5. Airflows 1-4 and the mean maximum winter temperature distribution, illustrating adret heating on the north (sun) facing slopes.

temperatures over the district and the spatial patterns reflected strong surface heat accumulation with every airflow type. However, the actual maximum temperatures varied quite considerably between the airflow types, which were associated with the stability/cloud cover contrasts and the advected heat from the interior of the continent with westerly airflows 2 (cyclonic) and 4 (anticyclonic). For example, the highest maxi- mum temperature in the eastern floodplain $(28.0 \mathrm{C})$ was observed with the cyclonic continental airflow 2 circulation (Fig. 4b) and was $1.1 \mathrm{C}$ above the anticyclonic rnaritime airflow 3 maximum (Fig. 4c) which represented cooler oceanic air. The degree of surface heat accumulation varied appreciably with the airflow circulation since the dry adiabat was exceeded by $0.3 \mathrm{C}$ with airflow 1 (Fig. 4a), 0.5C with airflow 2 (Fig. 4b),

TABLE 5. Mean minimum temperatures $\left({ }^{\circ} \mathrm{C}\right.$ ) and airflow types for the Armidale district, New South Wales '(1 October 1966-30 September 1967).

\begin{tabular}{|c|c|c|c|c|c|c|c|c|c|c|c|c|}
\hline \multirow[b]{2}{*}{ Station/environment } & \multicolumn{3}{|c|}{$\begin{array}{c}\text { Airflow } 1 \\
\text { (Cyclonic maritime) }\end{array}$} & \multicolumn{3}{|c|}{$\begin{array}{c}\text { Airflow } 2 \\
\text { (Cyclonic continental) }\end{array}$} & \multicolumn{3}{|c|}{$\begin{array}{c}\text { Airflow } 3 \\
\text { (Anticyclonic maritime) }\end{array}$} & \multicolumn{3}{|c|}{$\begin{array}{c}\text { Airflow } 4 \\
\text { (Anticyclonic continental) }\end{array}$} \\
\hline & Year & Winter & Summer & Year & Winter & Summer & Year & Winter & Summer & Year & Winter & Summer \\
\hline A. Lower adret & 10.1 & 6.1 & 14.1 & 4.8 & 1.6 & 13.3 & 8.8 & 2.9 & 13.0 & 1.5 & -0.6 & 12.8 \\
\hline C. Middle ubac & 10.2 & 7.3 & 14.1 & 5.0 & 1.2 & 13.5 & 8.7 & 3.1 & 13.4 & 1.4 & -0.3 & 13.1 \\
\hline D. Upper adret & 10.8 & 7.7 & 14.8 & 6.7 & 3.4 & 14.1 & 9.7 & 4.1 & 14.0 & 3.2 & 1.3 & 13.5 \\
\hline E. Crest North Hill & 10.4 & 7.9 & 14.8 & 6.8 & 3.8 & 14.1 & 9.2 & 4.2 & 13.8 & 4.2 & 2.2 & 13.8 \\
\hline F. Floodplain (urban) & 9.5 & 5.3 & 13.9 & 3.9 & -0.8 & 13.2 & 8.5 & 2.1 & 13.0 & 0.8 & -1.5 & 12.8 \\
\hline G. Middle adret & 10.4 & 7.3 & 14.5 & 5.3 & 1.3 & 13.6 & 9.2 & 3.1 & 13.4 & 1.8 & -0.1 & 13.2 \\
\hline H. Floodplain (eastern) & 10.0 & 6.1 & 14.3 & 4.9 & 1.3 & 13.1 & 8.6 & 3.1 & 12.6 & 1.2 & -1.0 & 12.8 \\
\hline
\end{tabular}



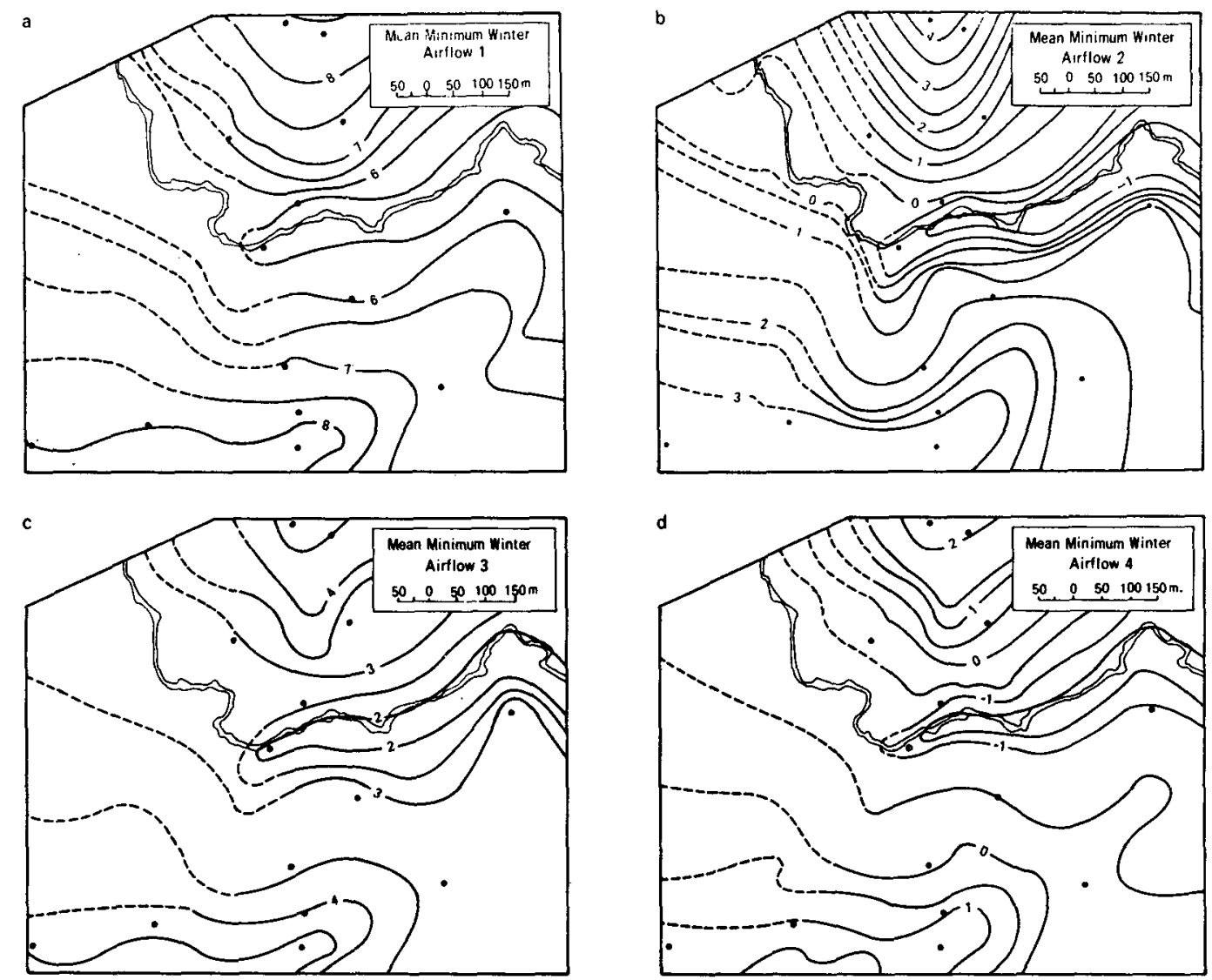

FIG. 6. Airflows 1-4 and the mean minimum temperature distribution, illustrating cold air drainage and inversion of temperature.

$0.9 \mathrm{C}$ with airflow 3 (Fig. $4 \mathrm{c}$ ), and $0.4 \mathrm{C}$ with airflow 4 (Fig. 4d). The most extreme lapse rate steepening of airflow 3 was almost twice the dry adiabatic rate and reflected both the characteristic dynamic subsidence and summer dominance ( $35 \%$ frequency, Table 2$)$ of this anticyclonic maritime circulation.

The distribution of winter maximum temperatures (Fig. 5) largely reflected the adret heat concentration on the middle slopes of South Hill (station G) with all the airflow types. The temperature lapse rate between the floodplain and North Hill crest approximated the dry adiabatic rate at this time (e.g., within $0.2 \mathrm{C}$ with airflows 1, 2 and 3) apart from airflow 4 where the temperature decrease of $2 \mathrm{C}(100 \mathrm{~m})^{-1}$, or twice the dry adiabat (Fig. 5d), emphasized the surface heat accumulation which was associated with stable anticyclonic conditions. The degree of adret heating varied quite considerably between the circulations [for example airflow 1, 1.1C (Fig. 5a); airflow 2, 1.0C (Fig. 5b); airflow 3, 1.2C (Fig. 5c); airflow 4, 1.4C (Fig. 5d)]. The heating variations were associated with the stability/cloud contrasts between cyclonic and anti- cyclonic types and the greatest adret heating of the airflow 4 types reflected the sunny, clear weather of this anticyclonic continental circulation.

\section{2) Minimum temperatures}

The distribution was influenced primarily by the elevation and slope variations in the district, and the floodplain minimum temperatures were well below the hillcrest minima during most of the months of the observation period. The resultant increase of temperature with altitude represented a complete reversal of the dry adiabatic rate and strong temperature inversions developed.

The relationship between minimum temperature distribution and airflow types is indicated in Table 5 and various aspects are illustrated in Figs. 6 and 7. The annual, winter and summer temperature differences between stations $\mathrm{E}$ (North Hill crest) and F (floodplain) in Table 5 emphasize the dominant cold air drainage and temperature inversion with the four airHow circulations. However, the degree of cold air drainage varied quite considerably, according to the 

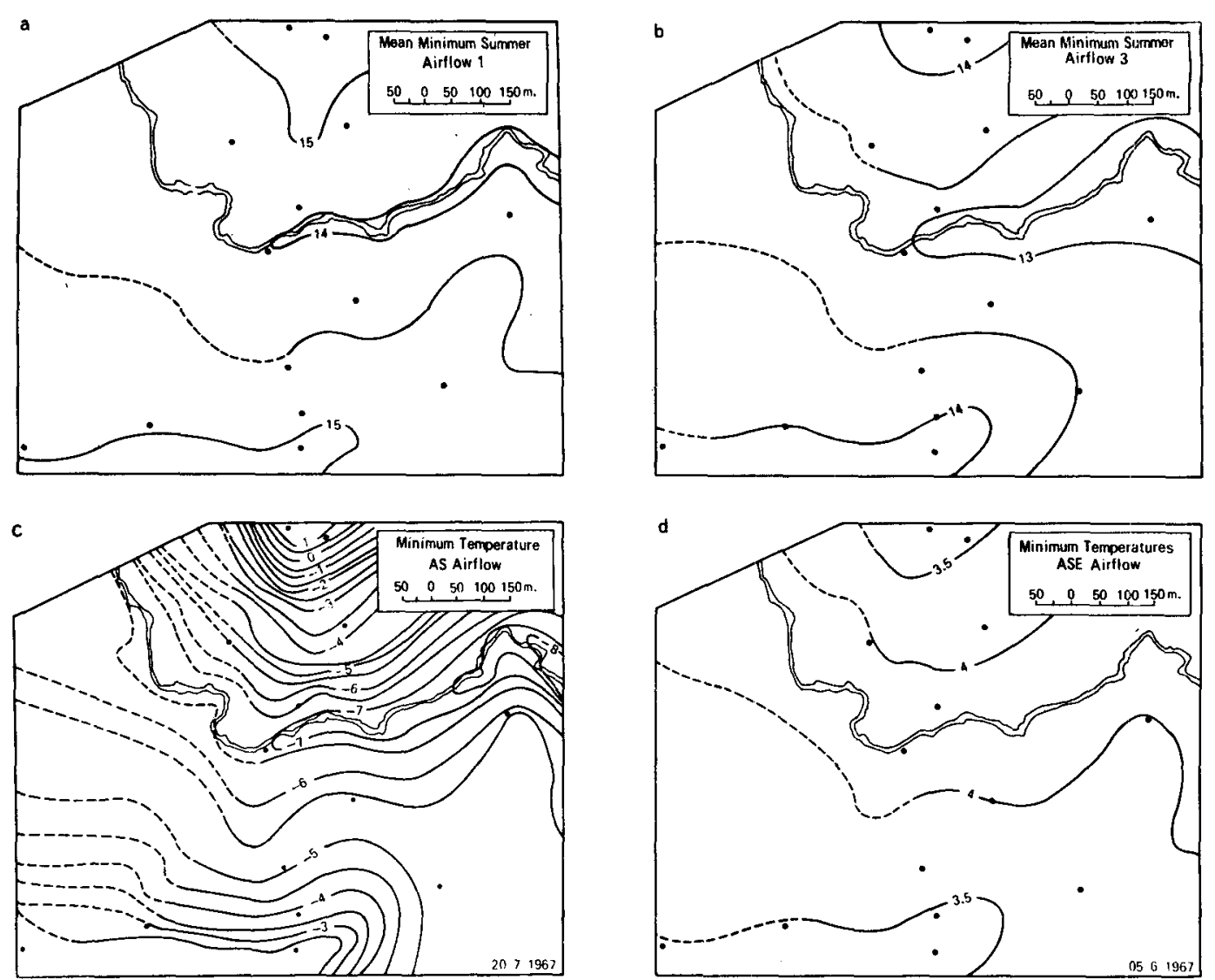

FIg. 7. Airflow types and minimum temperature distribution for mean summer airforws 1 and 3 (a, b); winter mean minimum temperatures and strongest inversion recorded for airflow 4 [AS hybrid type] (c); and winter mean minimum temperatures for airflow 3 [ASE hybrid type] (d).

season of the year and the continentality/stability of the airflow, and was relatively weak with summer situations and maritime airflows (both cyclonic and anticyclonic). For example, Table 5 reveals that the annual minima of the continental airflows 2 and 4 averaged up to $8.7 \mathrm{C}$ lower than the airflow 1 (cyclonic maritime) values, where greater cloud cover and turbulence retarded intensive radiative chilling/cold air drainage and where advective warm air from the Pacific moderated nocturnal temperatures. The temperature inversions recorded with the continental airflows ranged between -2.9 and $-3.4 \mathrm{C}(100 \mathrm{~m})^{-1}$ [more than three times the maritime inversions], with the stronger inversion related to the more stable anticyclonic 4 conditions.

Fig. 6 illustrates the distribution of winter minimum temperatures, which confirmed the mean annual patterns outlined above. The actual winter minima were naturally much lower than the annual values since terrestrial radiation and katabatic airflow were more effective on the long winter nights. However, the maritime airflow minimum temperatures exceeded 2.0C (Figs. 6a and 6c) which indicated the infuence of marine moderation and greater turbulence/cloud cover throughout the year, although the lower anticyclonic airflow 3 values (Fig. 6c) were influenced by the dynamic subsidence and greater radiative chilling consequent upon the clear skies and reduced wind speed. The winter temperature inversions associated with these maritime airflows averaged between -2.1 and $-2.6 \mathrm{C}(100 \mathrm{~m})^{-1}$. with the higher value related to the cyclonic circulation despite the more unsettled conditions.

The continental airflow winter minimum temperatures were below $0 \mathrm{C}$ in the floodplain (Figs. 6b and 6d) and the anticyclonic airflow 4 minimum (Fig. 6d) was $5.8 \mathrm{C}$ below that of the cyclonic maritime circulation (Fig. 6a). The temperature inversions averaged between -3.7 and $-4.6 \mathrm{C}(100 \mathrm{~m})^{-1}$ which indicated that the cold air drainage was aggravated by the advective cold air, particularly with the stronger inversion of the cyclonic circulation (Fig. 6b). Fig. $7 \mathrm{c}$ refers to the 
coldest night of the year which was associated with the anticyclonic stability/radiative chilling of the airflow 4 circulation (hybrid type AS) and where the resultant cold air drainage was accentuated by the southerly (polar maritime) airflow. The minimum temperatures ranged from $-8.5 \mathrm{C}$ in the eastern rural floodplain (away from the air drainage hindrance/latent heat release of buildings) to $1.1 \mathrm{C}$ on the crest of North Hill, with a very strong temperature inversion of $-9.6 \mathrm{C}$ $(100 \mathrm{~m})^{-1}$. Conversely, on cloudy turbulent winter nights (Fig. 7d), cold air drainage was minimized and the dry adiabatic rate of cooling was recorded between the floodplain and the hillcrests.

The mean summer minimum temperatures exceeded $12.6 \mathrm{C}$ with every airflow type, with the highest value (14.8C) recorded on the upper slopes of North Hill. However, the distribution of temperatures over the district once again reflected the influence of cold air drainage since the coldest conditions were experienced in the low-lying eastern floodplain. The short, turbulent summer nights did not allow excessive katabatic airflow and consequently the weak temperature inversion averaged about $-1 \mathrm{C}(100 \mathrm{~m})^{-1}$. Figs. $7 \mathrm{a}$ and $7 \mathrm{~b}$ represent the typical summer distribution of minimum temperatures which was characterized by mild conditions $(>12.6 \mathrm{C})$ and very weak temperature inversions of between -0.9 and $-1.2 \mathrm{C}(100 \mathrm{~m})^{-1}$.

3) Significance testing of the associations BeTWEEN MAXIMUM/MINIMUM TEMPERATURES AND AIRFLOW TYPE

The non-parametric "two-tailed" KolmorogovSmirnov test was applied to data in order to determine the significance of the floodplain/North Hill temperature differences per airflow circulation. The maximum temperatures were only significantly different $(<5 \%$ level) with the anticyclonic maritime airflow 3 where surface heat accumulation was facilitated by the stability and insolation concentration associated with its summer dominance. The remaining associations were not significant at the arbitrary $5 \%$ level and the lack of any real "proven" difference supported the earlier spatial observations that airflows 1,2 and 4 are not conducive to maximum amounts of heat accumulation. The significant minimum temperature differences were associated with the continental airflows 2 (cyclonic) and 4 (anticyclonic) which allowed advective cold air transfers and in situ cold air drainage. The remaining associations confirmed the "no difference" null hypothesis and indicated that maritime circulations did not allow radiative chilling/katabatic airflow and strong temperature inversions (supporting the earlier spatial relationships).

Table 6 indicates the correlation coefficients and significance testing between the temperature fluctuations of the floodplain and North Hill crest stations. Maximum temperatures were characterized by a very
TABLE 6. Correlation coefficients $(r)$ and significant test $(t)$ between the mean temperatures at the floodplain (Station $F$ ) and North Hill crest (Station E) for different airflows.

\begin{tabular}{ccccc} 
Airflow & $\begin{array}{c}\text { Mean annual } \\
\text { maximum temperature } \\
r\end{array}$ & $t^{*}$ & $\begin{array}{c}\text { Mean annual } \\
\text { minimum temperature } \\
t^{*}\end{array}$ & $=$ \\
\hline 1 & +0.97 & $\mathrm{~S}$ & +0.85 & $\mathrm{~S}$ \\
2 & +0.95 & $\mathrm{~S}$ & +0.27 & $\mathrm{NS}$ \\
3 & +0.98 & $\mathrm{~S}$ & +0.91 & $\mathrm{~S}$ \\
4 & +0.96 & $\mathrm{~S}$ & +0.25 & $\mathrm{NS}$
\end{tabular}

* NS, not significant at the $5 \%$ level; S, significant below the $5 \%$ level.

high degree of positive correlation $(r \geqslant 0.95)$ with the four airflow circulations; furthermore, these associations were all significant below the $5 \%$ level, indicating that the variability of temperatures was very close at the two sites with every airflow type. The minimum temperatures had more variable associations in that only the two maritime airflows 1 and 3 were characterized by a high degree of positive correlation $(r \geqslant 0.85)$. The continental airflows 2 and 4 experienced a very low degree of correlation $(r \leqslant 0.27)$ which meant that temperature decreases in the floodplain were not related to similar fluctuations on the hill crest. This independence implies that the continental circulations are dominated by cold air drainage which is more effective in the lowest parts of the floodplain.

\section{Conclusions}

It is apparent that considerable mesoclimatic contrasts characterize the Armidale district which closely reflect the minor relief variations in the area, associated with elevation, slope and aspect. Furthermore, since the local amplitude of relief in the Dumaresq Valley represents the so-called Pliocene surface of the New South Wales escarpment, the mesoclimatic variations can be assumed to represent a significant part of "upland" New South Wales.

The spatial distribution of rainfall and temperature over the district was quite remarkable and the patterns varied considerably between the airflow circulations, associated with their distinctive stability/advection characteristics. For example, total rainfall with cyclonic airflows 1 and 2 was concentrated over the eastern floodplain whereas the total rainfall related to the anticyclonic circulations was deposited over North Hill, reflecting the influence of orographic uplift with airflows dominated by dynamic subsidence. Maximum temperature patterns were directly influenced by the relief contrasts, since the annual and summer means were dominated by surface heat accumulation in the sheltered floodplain, where the steepening lapse rate exceeded the dry adiabatic rate. The winter maximum temperature distribution emphasized the role of aspect, since the north-facing adret slopes recorded higher temperatures 
than the ubac slopes facing away from the sun. Cold air drainage influenced the minimum temperature patterns over the district, and the resultant temperature inversions caused floodplain minima to be much lower than those of the hill crest.

However, it must be noted that the outstanding temperature contrasts and associated mesoclimatic imbalance are eliminated under unstable cyclonic conditions when the related cloud and turbulence minimize radiative chilling/katabatic airflow and heat accumulation. Consequently, temperature inversions, floodplain heat accumulation and adret heating were experienced mostly under conditions of anticyclonic stability (i.e., airflows 3 and 4) since calm clear weather was an essential prerequisite for their development. For example, the anticyclonic maritime airflow 3 was responsible for $42 \%$ of all inversions, $64 \%$ of all surface heat accumulation days, and $46 \%$ of all adret heating days. Furthermore, chi-square tests were applied to these frequency relationships and the anticyclonic preference was supported by significance levels below $5 \%$ in every case.

Acknowledgments. The author wishes to acknowledge the valuable assistance and cooperation of Prof. G. Butland, University of New England, Mr. E. Fitzpatrick, University of Western Australia, and Dr. R. G. Barry, University of Colorado. The Australian Bureau of Meteorology supplied the daily synoptic charts which formed the basis of the airflow classification.

\section{REFERENCES}

Barrett, E. C., 1967 : Viewing Weather from Space. London, Longmans, p. 38.

Barry, R. G., 1967 : The prospect for synoptic climatology: A case study. Liverpool Essays in Geography, Steele and Lawton, Eds., London, Longmans, 85-106.

Baur, F., 1951 : Extended-range weather forecasting. Compendiztm of Meteorology, T. Malone, Ed., Boston, Amer. Meteor. Soc., 814-33.

Bluthgen, J., 1965: Synoptische Klimageographic. Geograph. Z., $53,10-51$.

Bureau of Meteorology Australia, 1963: Report on the development of a flood forecasting system for the lower Macleay River Valley, New South Wales. No. 4, 1-28.

Foley, J. C., 1945: Frost in the Australian region. Bureau of Meteorology, Bull. No. 32 .

Godske, C. L., 1959: Information, climatology and statistics. Geograf. Ann., 41, 85-93.

Hannay, F., 1960; Cold outbreaks in southern Australia in relation to sub-antarctic circulations. Antarctic Meteorology, London, Pergamon, 153-175.

Hills, E. S., 1966: Physical Geography. The Australian Environment, Melbourne University Press, Chap. 1.

Lamb, H. H., 1950: Types and spells of weather around the year in the British Isles: Annual trends, seasonal structure of the year, singularities. Quart. Roy. Meteor. Soc., 76, 393-429.

Mosino, P. A., 1964: Surface weather and upper airflow patterns in Mexico. Geofis. Intern., 4, 117-168.

Thompson, R. D., 1971: The dynamic climatology of northeast New South Wales. Ph.D. thesis, University of New England, Armidale.

-- 1973: The contribution of airflow circulation to local temperatures and rainfall in the New England area, N.S.W., Australia. Arch. Meteor. Geophys. Bioclim., B21, No. 1 (in press). 